\title{
Fresh-Cut Produce: Comparison Between Sanitation and Production Methods: Organic Versus Conventional
}

\author{
Háquila Mirelly Franco Vieira Reis Marques ${ }^{1}$, Christian Boller ${ }^{1 *}$, \\ Rossana Catie Bueno de Godoy ${ }^{2}$ and Maria Rosa Machado Prado ${ }^{1}$ \\ ${ }^{1}$ Faculdades Pequeno Príncipe, Curitiba, Paraná, Brasil \\ ${ }^{2}$ Embrapa Florestas, Colombo, Paraná, Brasil \\ *Corresponding author
}

\begin{abstract}
A B S T R A C T
Keywords

Fresh-cut, Produce,

Organic, Conventional,

sanitation

Article Info

Accepted:

23 March 2018

Available Online:

10 April 2018

The aim of this review is to create awareness to the fact that fresh-cut produce may be a low-risk choice. Furthermore, it can briefly address the challenges faced by the food industry to provide consumers with highquality and safe products. Health concerns continue to influence people worldwide to seek healthier habits. Fresh cut produce is widely consumed for being a healthy, practical and convenient alternative. Food industries all over the globe are committed to provide the population with a variety of fresh-cut produce. In order to achieve quality standards, fresh-cut processing includes one or more sanitation steps to reduce microbial load.
\end{abstract}

\section{Introduction}

Over the last couple of years there is been an increase in the demand and consumption on fruits and vegetables. Health related and fitness related concerns have led many people to reflect about their dietary habits and search for healthier alternatives (Alves et al., 2007; Allende et al., 2009; Artés et al., 2009; Darolt, 2003). Organic foods, for example, are gaining in popularity for their nutritional benefits and sustainable cultivation methods which are believed to have a positive impact on food quality. However, even with a wide acceptance and demand for organics, conventional foods continue to lead the ranks in both categories. The food industry doesn't stay far behind when it comes to pleasing their customers and boosting sales. Many industries and small producers have invested in Fresh Cut (FC) fruits and vegetables. The growing popularity of FC is mainly because of its convenience and nutritious alternative to regular fast foods (Abbott et al., 2004; Beltran et al., 2005).

With the variety of both organic and conventional FC produce to choose from, consumers worldwide are faced with a serious question, "Which foods are safer and healthier to eat?" There is still much controversy regarding the nutritional benefits and the 
safety of organic foods. In order to help consumers with their choice, research has strived to provide populations with as much detailed information by conducting studies that compare both foods (Smith-Spangler et al., 2012, Magkos et al., 2006).

Results of various studies show that both organic and conventional foods have their benefits and drawbacks. Nutritionally, the differences between them are not significant enough for scholars to defend one more than the other. As for which is safer? Both contain known and potent risks to human health and much attention needs to be drawn on how to prevent or minimize them, especially microbiological contamination which is the most common (Forman and Silverstein, 2012; Maffei et al., 2013; Smith-Spangler et al., 2012; Magkos et al., 2006).

FC are not a low risk choice. Actually, there is a higher chance of contamination with FC than with whole produce (Gil et al., 2009). Although sanitation is a part of the preparation process, no food is $100 \%$ contamination free. Contamination can occur any time during the industrial process, packaging, transportation, storage and even through cross contamination (Forman and Silverstein, 2012; SmithSpangler et al., 2012; Magkos et al., 2006). This review aims to draw attention to possible microbiological contamination in fruits and vegetables of both conventional and organic fresh cut produce.

\section{Organic and conventional production}

Health and environmental concerns are the main reasons for the growing interest in organic foods. There is very little evidence that organic is safer and healthier when compared to conventional (Garcia and Teixeira, 2016). Currently, the strongest argument that sides with organic produce is due to its environmentally sustainable cultivation method. Organic farming does not use synthetic fertilizers, antibiotics or growth hormones. Crop rotations, crop residues and animal manure provide the soil with the necessary nutrients for cultivation. Biological controls, physical and mechanical methods are used to handle pests, weeds and other contaminants. Standards, although strict globally, vary from country to country.

Organic fruits and vegetables are among the most popular organic products consumed (Alves et al., 2007; Forman and Silverstein, 2012; Smith-Spangler et al., 2012; Mulet, 2014, Skwarlo-Sonta et al., 2011). Studies demonstrate that consumers of organic foods are mostly people that are highly educated and with higher income, therefore share the same concerns in regard to health and the environment (Shi-Ming et al., 2006; Mulet, 2014; Saba et al., 2003; Shafie et al., 2012). Food quality and safety are also a major concern among those who buy organic products, so the use of certifiers' seals is definitely the best way to check information that brings safety (Bartels et al., 2010; Bellows et al., 2010; Saher et al., 2006; Stolz et al., 2011).

Even though the green peace movement that promotes living a healthier more environmentally conscious life. It has gained in popularity and conventional foods continue leading sales rankings (Smith-Spangler et al., 2012; Stolz et al., 2011). This is mainly due to lower prices when compared to organic and also because majority of the worldwide population is used to consuming conventionally grown produce.

For years, conventional food has been the most consumed especially in developing countries. Conventional farming includes a variety of cultivation and farming methods as well as many substances and additives. There are a number of synthetic pesticides including 
those used to manage pests, weeds and other contaminants. It is common the use of hormones, antibiotics, genetic engineering and irradiation in conventional agriculture (DePonti et al., 2012; Skwarlo-Sonta et al., 2011; Smith-Spangler et al., 2012; Stolz et al., 2011). It is known that the difference between organic and conventional foods is directly related to the form of cultivation as demonstrated in Figure 1.

\section{Fresh-cut produce}

Busy lives and the demand for healthier foods have led to a major increase in FC consumption. FC produce is ready to eat raw fruits and vegetables which contents are $100 \%$ usable. FC produce should be as similar as possible to freshly prepared produce in organoleptic characteristics, nutritional value and safety. The preparation process of FC include the following steps: receiving, separation, pre cooling, washing, disinfection, peeling, trimming, deseeding, cutting, dipping, drying, packaging, labelling, storage and distribution as shown in Figure 2. Removing the natural barrier by pealing and cutting increases the risk of contamination. The surface can become moist and expose nutrients that favor microbial growth (Artés et al., 2009; Choi et al., 2012; Gil et al., 2009; López-Gálvez et al., 2009; Ölmez et al., 2009; Ruiz-Cruz et al., 2007; Tornuk et al., 2011).

The growing demand for FC has gotten a lot of attention because of the increased risk of microbiological contamination. FC has been responsible for a number of foodborne outbreaks over the past few years (Ölmez et al., 2009). Processing steps such as peeling and cutting can lead to microbial growth at the cut surface. By breaking the protective surface, nutrients are exposed enhancing microbial growth. Bacteria can easily adhere to wounded produce, making its removal difficult even with use of sanitizers (Allende et al., 2009,Gil et al., 2009,Ruiz-Cruz et al., 2007).

The risk of microbiological contamination in FC is a lot higher when compared to whole produce. In order to achieve the standards of quality, safety and nutritious values, industries invest a lot on sanitation methods that best suppress microbial growth during processing and post-processing preventing contamination (Arts et al., 2009). Reduction of microorganisms and pathogens is only possible to accomplish by properly sanitizing produce during processing (Allende et al., 2009).

\section{Contamination}

Food security is a huge if not the number one concern among consumers of both conventional and organic foods. The widespread belief that organic food is healthier and safer than conventional foods is associated with disadvantages proven by the use of pesticides. They also consider conventional cultivation methods aren't safe for the environment. However, from a food safety point of view there are many potent risks of contamination within organic mainly microbiological contamination (Rossi et al., 2010; Choi et al., 2012; Gil et al., 2009; Langsrud et al., 2003; López-Gálvez et al., 2009; Maffei et al., 2013; Magkos et al., 2006; Ölmez et al., 2009; Smith-Spangler et al., 2012).

Biological production differs from conventional production methods in a number of ways and can influence the composition of the end product. The use of manure instead of chemical fertilizers, in fact, contributes to an increased risk of microbiological contamination.

Use of treated and non-treated manure is common in organic and conventional 
agriculture as crop fertilizer. Therefore, potential risk factors appear to apply equallywith regards to the origin of contamination (Rossi et al., 2010; Choi et al., 2012; Gil et al., 2009; Langsrud et al., 2003; López-gálvez et al., 2009; Maffei et al., 2013; Magkos et al., 2006; Ölmez et al., 2009; Smith-spangler et al., 2012).

The main contaminants present in produce which have been proven to pose risks to human health are: synthetic agricultural chemicals, environmental pollutants, nitrate content, contaminants in food and food products of animal origin, natural plant toxins, biological pesticides, microbial pathogens and mycotoxins (Arts et al., 2009; Gil et al., 2009).

Microbiological contamination in both farming methods is mostly caused by Salmonella and Escherichia coli O157. In organically grown products, this is mainly due to the use of natural manure and poor water control. Not only can natural manure increase the risk of contamination it can also elevate levels of heavy metals present in the produce.

In conventional farming, the use of pesticides during cultivation greatly reduces the number of microorganisms, the problem often lies after the produce reaches the market. Poor handling at the market can lead properly treated and cultivated produce to be contaminated by coming in to contact with potential food pathogens from other foods or the environment (Maffei et al., 2013; Ramos et al., 2013).

Contamination can occur any time during cultivation, harvest, post-harvest handling, processing, transportation, distribution, marketing, even at home. No food is $100 \%$ free of the risk of microbiological contamination. Therefore, sanitation practices throughout the cultivation process, packaging and marketing is highly required. It is extremely important to draw awareness of the importance of sanitizing fruits and vegetables properly prior to consumption (Maffei et al., 2013; Gil et al., 2009). Table 1 cites the main microorganisms frequently found in fruits and vegetables.

When it comes to food contamination regardless of the cultivation and production processes FC products have been implicated in major outbreaks of foodborne illnesses. Therefore, there was an increase in research and studies for alternative sanitation methods for FC (Arts et al., 2009; Gil et al., 2009; Arvaniti et al., 2006).

\section{Sanitation}

Sanitizing food prior to consumption or during the processing does not eliminate microbiological contaminants, it only reduces the risk of contamination. Nonetheless, sanitation is standard in all food processes in order to achieve high levels of safety (Artés $e t$ al., 2009; Choi et al., 2012; López-gálvez et al., 2009; Ruiz-cruz et al., 2007; Tornuk et al., 2011; Velázquez et al., 2009; Meireles et al., 2016).

In conventional production, many decontamination methods are used, such as irradiation, antimicrobials, chemical washes, disinfectants and others. However, these aforementioned methods are strictly prohibited in organic production. Some sterilization methods such as pasteurization and chlorinated water may be optional in organic production. Although given the matter of risk, not all organic farmers practice pasteurization and chlorinated wash (Choi et al., 2012; Goodburn et al., 2013; Ramos et al., 2013; Meireles et al., 2016). 
Table.1 Main contaminants found in produce

\begin{tabular}{|c|c|c|}
\hline Produce & Microorganism & Reference \\
\hline Fresh-cut cilantro & $\begin{array}{l}\text { Salmonella, Escherichia coli } \\
\text { O157:H7 and Listeria } \\
\text { monocytogenes. }\end{array}$ & (Allende et al., 2009) \\
\hline $\begin{array}{l}\text { Shredded lettuce, Chinese } \\
\text { cabbage, apple, strawberry } \\
\text { and cantaloupe }\end{array}$ & L. monocytogenes & (Artés et al., 2009) \\
\hline Lettuce & $\begin{array}{lr}\text { Enterobacter } & \text { sakazakii, } \\
\text { aerobic bacteria, } & \text { Shigella } \\
\text { sonnei coliform } & \text { bacteria, } \\
\text { molds, and yeasts } & \end{array}$ & (Artés et al., 2009) \\
\hline Carrots and apples & $\begin{array}{l}\text { E. coli } \mathrm{O} 157: \mathrm{H} 7 \text { and } S . \\
\text { typhimurium }\end{array}$ & (Tornuk et al., 2011) \\
\hline Spinach and Lettuce & $\begin{array}{l}\text { Listeria monocytogenes, } \\
\text { Salmonella typhimurium, and } \\
\text { Escherichia coli } \mathrm{O} 157: \mathrm{H} 7\end{array}$ & (Choi et al., 2012) \\
\hline $\begin{array}{l}\text { Organic and conventional } \\
\text { vegetables: lettuces (Lactuca } \\
\text { sativa L.), chicory, catalogna } \\
\text { (Cichorium intybus L.), } \\
\text { collard greens (Brassica } \\
\text { oleracea L.), arugula (Eruca } \\
\text { sativa L.) }\end{array}$ & $\begin{array}{l}\text { Mesophilic aerobic bacteria, } \\
\text { yeasts and molds, total } \\
\text { coliforms and } E \text {. coli }\end{array}$ & (Maffei et al., 2013) \\
\hline Lettuce & $\begin{array}{l}\text { Listeriamonocytogenes, } \\
\text { Escherichia coli O157:H7 }\end{array}$ & (Ölmez et al., 2009) \\
\hline Parsley & $\begin{array}{l}\text { Yersiniaenterocolitica, } \\
\text { Shigellasonnei }\end{array}$ & (Ölmez et al., 2009) \\
\hline Tomatoes & Salmonella entérica & (Ölmez et al., 2009) \\
\hline Apples & $\begin{array}{l}\text { Salmonella and } \quad E . \quad \text { coli } \\
\text { O157:H7 counts }\end{array}$ & (Ölmez et al., 2009) \\
\hline Carrots & $\begin{array}{l}\text { E. coli } \mathrm{O} 157: \mathrm{H} 7 \text { and } L . \\
\text { monocytogenes counts }\end{array}$ & (ÖLMEZ et al., 2009) \\
\hline Potatoes & $\begin{array}{l}\text { E. coli, mesophilic and } \\
\text { psychrotrophic bacteria }\end{array}$ & (Beltran et al., 2005) \\
\hline Grapes & $\begin{array}{l}\text { aerobic mesophilic bacterial, } \\
\text { yeast and mold }\end{array}$ & (Fan et al., 2008) \\
\hline $\begin{array}{l}\text { Bagged baby spinach and } \\
\text { Bagged shredded lettuce }\end{array}$ & Escherichia coli O157:H7 & (Sharma et al., 2009) \\
\hline
\end{tabular}


Fig.1 Comparison between organic and conventional foods

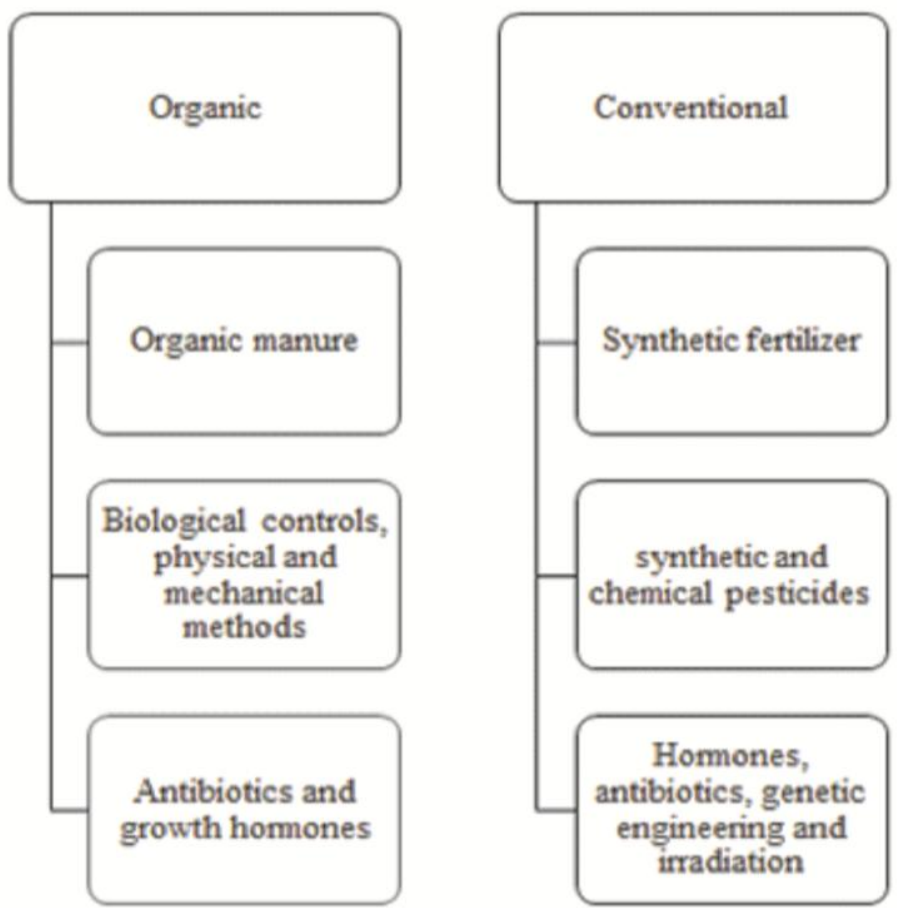

Adapted from SMITH-SPANGLER et al., 2012, FORMAN, SILVERSTEIN, 2012.

Fig.2 Fresh cut processing stages

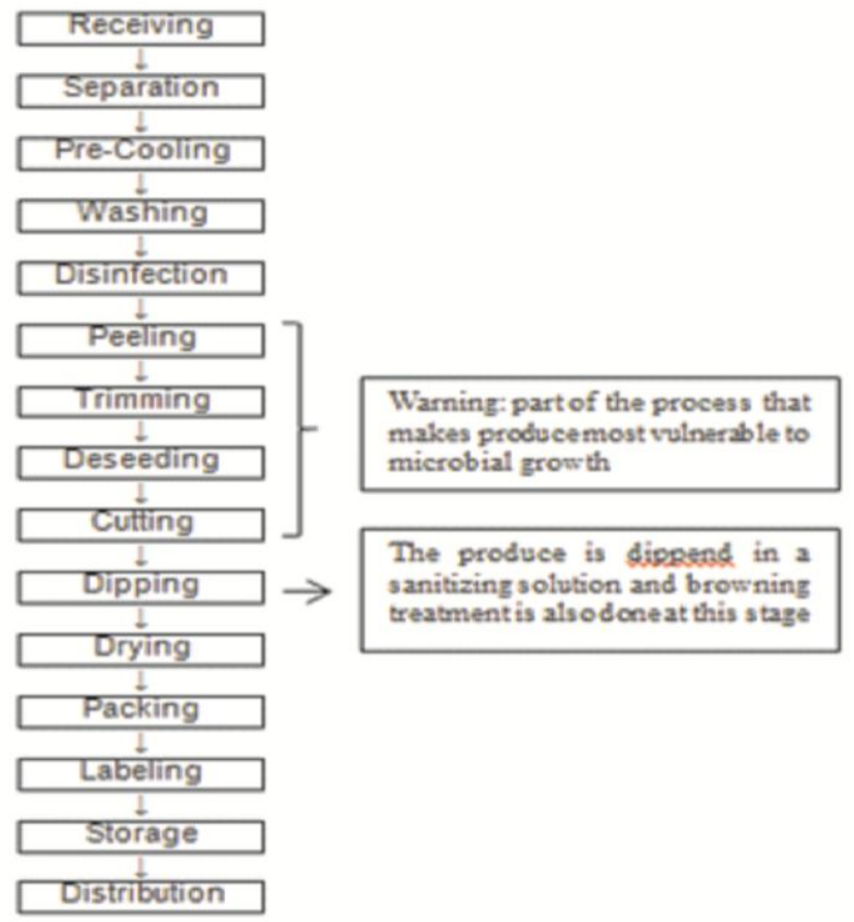

For food sanitation some substances are allowed, but it is always necessary to make an 
evaluation of what is indicated for the type of cleaning to be sanitized.

\section{Organic acids}

Organic acids are known to act as a bactericide against food-borne pathogenic bacteria. They are also used as alternative sanitizers to chlorine as they have GRAS (Generally Recognized as Safe) status.

The main organic acids used widely are citric, lactic and acetic acid. It's antimicrobial activity is related to the environmental $\mathrm{pH}$ (Ölmez et al., 2009; Velázquez et al., 2009; Goodburn et al., 2013; Meireles et al., 2016).

Their mode of action is based on the acidification of the cytoplasm, disruption of proton motive force, osmotic stress and inhibition of macromolecule synthesis. Furthermore, they have a quick mode of action against an extensive range of bacteria grown under varying temperatures (Carpenter, 2009; Sagong et al., 2011). There are other organic acids that can be used in the food industry for fresh-cut to control microbial growth such as peracetic acid, propionic acid, malic acid (Da Silva et al., 2015; Meireles et al., 2016).

Downsides to its use are adverse effects on sensory quality such as the undesirable sour taste, discoloration and vinegar odor produced by this method. It also requires longer exposure time than other methods. The most crucial downside for the industry is the negative impact that organic acids have on wastewater quality. However, the organic acids were easy to use.no toxicity and allowed for organic products (Goodburn et al., 2013; Da Silva et al., 2015; Meireles et al., 2016).

\section{Chlorine}

Currently there are many methods of disinfection for both conventional and organic fresh-cut foods, which are feasible and are recommended by the United Nations Food and Agriculture Organization (FAO). The most common and practical substance used is chlorine. However, there are many concerns about the health benefits when considering the risks of this and other sanitization methods. Thus, further studies and research must be conducted to focus on finding alternative sanitation methods or improving existing ones (Maffei et al., 2013; Goodburn et al., 2013; Da Silva et al., 2015; Meireles et al., 2016).

For years, chlorinated water was considered the most common and efficient sanitation method worldwide. $\mathrm{NaClO}$ is a powerful oxidant, used extensively by the food industry worldwide to disinfect both products and processing equipment. The overall effectiveness, low cost gives it the versatility to be applied in small and large-scale operations. Its functionality is dependent on many factors such as: $\mathrm{pH}$, temperature, concentration, organic matter present in the wash water, exposure time, and the initial microbial load (Ölmez et al., 2009; Maffei et al., 2013; Goodburn et al., 2013; Da Silva et al., 2015; Meireles et al., 2016). There is a huge drawback concerning the use of $\mathrm{NaClO}$. It has proven to be harmful to human health. After many years of investigations and testing (laboratory and field), scientists and researchers have finally gathered, sufficient evidence that long-term use of chlorinated water as a sanitizer can have a negative impact on human life. Its byproducts have carcinogenic as well as mutagenic effects and may present toxicity risks (Ölmez et al., 2009; Velázquez et al., 2009; Maffei et al., 2013; Goodburn et al., 2013; Meireles et al., 2016).

Another advantage for of using chlorine is because it is easily accessible. In reference to the disadvantages and limitations associated with usage they are not allowed for organic 
products. Efficacy is affected by the presence of organic matter corrosive, activity $\mathrm{pH}$ dependent and reacts with organic matter (ÖLMEZ et al., 2009, VELÁZQUEZ et al., 2009, MAFFEI et al., 2013).

\section{Ozone}

Ozone is a great alternative to chlorine in many aspects. It has higher antimicrobial activity and is also approved in many countries where chlorine has been banned. It has gained GRAS (generally recognized as safe) widespread approval. For many years ozone treatment has shown to be effective against different kinds of bacteria, molds and yeast even at low concentrations and for short exposure times. Residue problems don't apply to ozone enabling the reuse and recycling process of water. It is not very easy to stabilize and it depends on many factors. Furthermore, it (ozone treatment) poses a drawback for the research community being that effective results are difficult to reproduce (Gil et al., 2009; Ölmez et al., 2009; Velázquez et al., 2009; Maffei et al., 2013).

Ozone is known to be a strong oxidative agent, which may harm the produce at certain concentrations. Studies have not demonstrated that ozone has much impact on the nutritional and sensory content of fruits and vegetables. One of the greater challenges for the industry regarding the use of ozone treatment is that high concentrations may cause potential corrosion of stainless steel. Another drawback of its use is it's high cost and not being allowed for use on organic products (Artés $e t$ al., 2009; Gil et al., 2009; Ölmez et al., 2009; Velázquez et al., 2009; Maffei et al., 2013).

\section{Peroxyacetic acid (PA)}

Peroxyacetic acid (PA), a mixture of acetic acid and hydrogen peroxide is gaining in popularity as an effective alternative to chlorine. As far as antimicrobial activity is concerned, it is effective against most pathogenic microorganisms even at low concentrations. The advantages of using peroxyacetic acid are: 1) efficacy is not affected by the organic load of water, 2) efficacy unaffected by temperature changes and not corrosive at permitted levels $\quad(<80$ ppm). However, the disadvantages are low for antimicrobial efficacy at permitted levels for vegetables and not allowed for organic products (Tornuk et al., 2011; Artés et al., 2009; Gil et al., 2009; Ölmez et al., 2009; Velázquez et al., 2009; Maffei et al., 2013).

Healthier eating habits are essential for reducing the incidence of certain diseases and living a better life. With the growing consumption of Fresh Cut (FC) fruits and vegetables, the population needs to be aware that FC is not a low risk alternative and may contain high levels of microbiological contamination. Proof that Chlorine, the main sanitizer used worldwide, may be harmful to human health represents a major drawback for the food industry and consumers. Researchers continue to discover and develop new sanitation methods do reduce the microbial loads of FC and help to provide safer FC produce.

\section{References}

Abbott, J.A., Saftner, R.A., Gross, K.C., Vinyard, B.T. and Janick, J. 2004. Consumer evaluation and quality measurement of fresh-cut slices of 'Fuji,' 'Golden Delicious,' 'GoldRush,' and 'Granny Smith' apples. Postharvest Biol Tec. 33, 127 - 140.

Allende, A., Mcevoy, J., Tao, Y. and LUO, Y. 2009. Antimicrobial effect of acidified sodium chlorite, sodium chlorite, sodium hypochlorite, and citric acid on Escherichia coli O157:H7 and natural 
microflora of fresh-cut cilantro. Food Control. 20, $230-234$.

Alves, S.L.C., Neves, M.C.P. and Costa, J.R. 2007. Avaliação da contaminação microbiológica de alface orgânica e convencional em diferentes pontos de comercialização. Embrapa. 105, 105 108.

Artés, F., Gomes, P.,Aguayo, E., Escalona, V. And Artés-Fernandes, F. 2009. Sustainable sanitation techniques for keeping quality and safety of fresh-cut plant commodities. PostharvestBiol Tec.51, $287-296$.

Bartels, J. and Reinders, M.J. 2010. Social identification, social representations and consumer innovativeness in an organic food context: a cross-national comparison. Food Qual Prefer. 24(4): $347-352$.

Bellows, A.C., Alcaraz, V.G. and Hallman, W.K. 2010.Gender and food, a study of attitudes in the USA towards organic, local, U.S. grown, and GM-free food. Appetite. 55(3): 540 - 550.

Beltran, D., Selma, M.V., Marin, A. and Gil, M.I. 2005. Ozonated water extends the shelf life of fresh-cut lettuce. J Agric Food Chem. 14, 439-448.

Beltran, D., Selma, M.V., Tudela, J.A. and GIL, M.I. 2005. Effect of different sanitizers on microbial and sensory quality of fresh-cut potato strips stored under modified atmosphere or vacum packaging. Postharvest Biol Tec, 2005, 37, $37-46$.

Carpenter, C.E. and Broadbent J.R. 2009. External concentration of organic acid anions and $\mathrm{pH}$ : Key independent variables for studying how organic acids inhibit growth of bacteria in mildly acidic foods. J Food Sci. 74 (1): 12-15.

Choi, M., Lee, S., Park, K., Chung, M., Ryu, S. and Kang, D. 2012. Effect of aerosolized malic acid against Listeria monocytogenes, Salmonella typhimurium, and Escherichia coli O157:H7 on spinach and lettuce.FoodControl. 24, $171-176$.

Da Silva, F.M., Kabuki, D.Y. and Kuaye, A.Y. 2015. Behavior of Listeria monocytogenes in a multi-species biofilm with Enterococcus faecalis and Enterococcus faecium and control through sanitation procedures. Int $\mathbf{J}$ Food Microbiol. 200, 5-12.

Darolt, M. R. 2003. Comparação da qualidade do alimento orgânico com o convencional. In Trigheta, P.C., Muniz, J.N. Alimentos Orgânicos: Produção, tecnologia e certificação.Press: Universidade Federal de Viçosa.289 312.

De Ponti, T., Rijk, B. and Van Ittersum, M.K. 2012. The crop yield gap between organic and conventional agriculture. Agric Syst. 108, 1 - 9.

Fan, X.,Annous, B.A., Beaulieu, J.C. and Sites, J.E. 2008. Effect of hot water surface pasteurization of whole fruit on shelf life and quality of fresh-cut cantaloupe. J Food Sci. 73(3): 91 - 98.

Forman, J. and Silverstein, J. 2012. Organic foods: health and environmental advantages and disadvantages. Pediatrics. 130, 1406 - 1415.

Garcia, J.M. and Teixeira, P. 2016. Organic versus conventional food: A comparison regarding food safety. Food Rev Int. In press.

Gil, M.I., Selma, M.V., Lopés-Gálvez, F. and Allende, A. 2009. Fresh-cut product sanitation and wash water disinfection: problems and solutions. Int $\mathrm{J}$ Food Microbiol. 134, 37 - 45.

Goodburn, C. and Wallace, C.A. 2013. The microbiological efficacy of decontamination methodologies for fresh produce: A review. Food Control. 32(2): 418-427.

Langsrud, S., Sidhu, M.S., Heir, E. and 
Holck, A.L. 2003.Bacterial disinfectant resistance - a challenge for the food industry. Int Biodeterior Biodegradation. 51(4): 283 - 290.

López-Galvez, F., Allende, A., Selma, M.V. and Gil, M.I. 2009. Prevention of Escherichia coli cross-contamination by different commercial sanitizers during washing of fresh-cut lettuce.Int J Food Microbiol. 133, $167-171$.

Maffei, D.F., Silveira, N.F. de A. andCatanozi, M. da P.L.M. 2013. Microbiological quality of organic and conventional vegetables sold in Brazil. Food Control. 29, 226 - 230.

Magkos, F., Arvaniti, F. and Zampelas, A. 2006. Organic food: buying more safety or just peace of mind? Crit Rev Food SciNutr.46, 23 - 56.

Meireles, A., Giaouris, E. and Simões, M. 2016. Alternative disinfection methods to chlorine for use in the fresh-cut industry. Food Res Int. 82, 71-85.

Mulet, J.M. 2014. Should we recommend organic crop foods on the basis of health benefits? Letter to the editor regarding the article by Barański et al., Br J Nutr.112, 1745 - 1747.

Ölmez, H. and Kretzschmar, U. 2009. Potential alternative disinfection methods for organic fresh-cut industry for minimizing water consumption and environmental impact. Food Sci Technol. 42, 686 - 693 .

Ramos, B., Miller, F.A., Brandão, T.R.S., Teixeira, P. and Silva, C.L.M. 2013.Fresh fruits and vegetables - An overview on applied methodologies to improve its quality and safety. Innov Food Sci. Emerg Technol. 20, 1 - 15.

Rossi, L.P.R. and Almeida, R.C. de C. 2010. Bacteriófagos para controle de bactérias patogênicas em alimentos. Rev Inst Adolfo Lutz. 69(2): 151-156.

Ruiz-Cruz, S., Acedo-Felix, E., Díaz-Cinco, M., Islas-Osuna, M.A. and Gonzáles-
Aguilar, G.A. 2007. Efficacy of sanitizers in reducing Escherichia coli O157:H7, Salmonella spp. and Listeria monocytogenes populations on freshcut carrots. Food Control. 18(1): 1383 1390.

Saba, A. and Messina, F. 2003. Attitudes towards organic foods and risk/benefit perception associated with pesticides. Food Qual Prefer.14 (8): 637 - 645.

Sagong, H-G., Lee, S-Y., Chang, P-S., Heu, S., Ryu, S. and Choi, Y-J.2011. Combined effect of ultrasound and organic acids to reduce Escherichia coli O157:H7, Salmonella typhimurium, and Listeria monocytogenes on organic fresh lettuce. Int J Food Microbiol.145 (1): $287-292$.

Saher, M., Lindeman, M. and Hursti, U-K.K. 2006. Attitudes towards genetically modified and organic foods. Appetite. 46(3): $324-331$.

Shafie, F.A. and Rennie, D. 2012. Consumer perceptions towards organic food. Procedia Soc Behav Sc. 49, 360 - 367.

Sharma, M., Patel, J.R., Conway, W.S., Ferguson, S. and Sulakvelidze, A. 2009. Effectiveness of bacteriophages in reducing Escherichia coli O157:H7 on fresh-cut cantaloupes and lettuce. J Food Prot. 72(7): 1481 - 1485.

Shi-Ming, M.A. andSauerborn, J. 2006. Review of history and recent development of organic farming worldwide. Agr Sci China. 5(3): 69 178.

Skwarlo-Sonta, K., Rembialkowska, E., Gromadzka-Ostrowska, J., SrednickaTober, D., Baranski, M., Kolikowski, T., Wisniewska, K., Rusaczonek, A., Hallmann, E. and Lueck, L. 2011. Response of animal physiology to organic versus conventional food production methods. NJAS Wagening $\mathrm{J}$ Life.58, 89 - 96 . 
Smith-Spangler, C., Brandeau, M.L., Hunter, G.E., Bavinger, J.C., Pearson, M., Eschbach, P.J., Sundaram, V., Liu, H., Schirmer, P., Stave, C., Olkin, I. and Bravata, D.M. 2012. Are organic foods safer or healthier than conventional alternatives? A systematic review. Ann Intern Med. 157, 348 - 366.

Stolz, H., Stolze, M., Janssen, M. and Hamm, U. 2011. Preferences and determinants for organic, conventional and conventional-plus products - The case of occasional organic consumers. Food Qual and Prefer. 22(8):772 - 779.

Tornuk, F., Cankurt, H., Ozturk, I., Sagdic,
O., Bayram, O. and Yetim, H. 2011. Efficacy of various plant hydrosols as natural food sanitizers in reducing Escherichia coli O157:H7 and Salmonella typhimurium on fresh cut carrots and apples. Int $\mathbf{J}$ Food Microbiol.148(1): 30 - 35 .

Velázquez, L. del C.,Barbini, N.B.,Escudero, M.E.andLucero, C. 2009. Evaluation of chlorine, benzalkonium chloride and lactic acid as sanitizers for reducing Escherichia coli O157:H7 and Yersinia enterocolitica on fresh vegetables. Food Control. 20(3): 262-268.

\section{How to cite this article:}

Háquila Mirelly Franco Vieira Reis Marques, Christian Boller, Rossana Catie Bueno de Godoy and Maria Rosa Machado Prado. 2018. Fresh-Cut Produce: Comparasion Between Sanitation and Production Methods: Organic Versus Conventional. Int.J.Curr.Microbiol.App.Sci. 7(04): 3038-3048. doi: https://doi.org/10.20546/ijcmas.2018.704.344 